\title{
A Dispute Systems Design Perspective on Norwegian Child Custody Mediation
}

\author{
Anna Nylund
}

\section{Contents}

1 Dispute Systems Design and Family Mediation .............................. 10

2 Child Custody Mediation from Facilitative Mediation to Diverse Mediation Models ...... 11

2.1 Child Custody Mediation as Facilitative Mediation ........................... 11

2.2 Adapting Mediation to the Needs of Diverse Families ...................... 12

2.3 Mediation Is Diluted to Settlement .................................... 13

3 Norwegian Child Custody Mediation Systems ................................ 14

3.1 Norwegian Welfare State as the Backdrop ............................. 14

3.2 Current Structure of Child Custody Mediation in Norway .................... 15

4 Critical Perspectives on Norwegian Child Custody Mediation ....................... 17

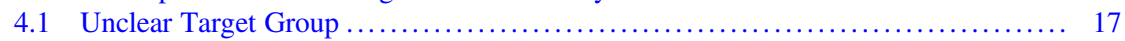

4.2 Overly Broad Definition of Mediation ................................. 19

4.3 Relationship Between the Three Tiers of Mediation ........................ 20

4.4 Particular Problems Related to Court-Connected Custody Mediation ............. 21

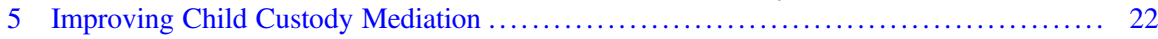

5.1 Recognising the Needs of High Conflict Families ......................... 22

5.2 Preventing Conflicts and Conflict Escalation ............................ 23

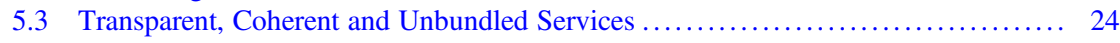

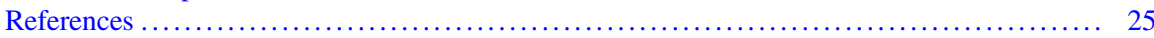

\begin{abstract}
In this article, I analyse why and how the Norwegian child custody system fails to provide early resolution to many families. Resolution of these conflicts should be timely and adapted to the level and sources of conflict. Child custody mediation is mandatory in Norway for all separating couples with children, yet the number of child custody disputes in courts is similar to the other Nordic countries with voluntary mediation schemes only. Particularly, high conflict families seem to receive inadequate services and support to manage their conflict, although the aim of the system is to prevent conflicts from being prolonged and escalating. In addition to an analysis of the failure of the system, I explore the different tiers of mediation services (the Family Counselling Office mediation and court-connected mediation)
\end{abstract}

\footnotetext{
A. Nylund $(\bowtie)$

Faculty of Law, University of Troms $\varnothing$ - The Arctic University of Norway, Troms $\emptyset$, Norway e-mail: anna.nylund@uit.no
} 
and their relationships - or lack thereof. This interrelationship influences the mediation system and its outcomes. To understand the context, I offer a brief account of the development of child custody mediation and give a societal background for the Norwegian child custody mediation system.

\section{Dispute Systems Design and Family Mediation}

Conflicts related to child custody and the amount of contact each parent should have following a divorce are a major challenge in contemporary Western societies. Prolonged high levels of conflict after parental separation is recognised as a central risk factor for the well-being of the children. Applying inappropriate mechanisms of dispute resolution may offer the parents no help in resolving their disputes and developing constructive co-parenting habits. Ultimately, inappropriate dispute resolution may result in prolonging the dispute and providing a solution that is not in the best interests of the child. The best interests of the child is the paramount factor in the resolution of disputes in custody and contact, along with the lifetime relationship between the parents vis-à-vis the child long after the separation.

The aim of dispute systems design theory is to help organisations and society manage and resolve disputes ${ }^{1}$ in an efficient and constructive manner (Rogers et al. 2013; Menkel-Meadow et al. 2010; Smith and Martinez 2009; Bingham 2008). By creating systems for early management, destructive conflicts are avoided. Organisations and society can then funnel resources into productive activities instead of unproductive methods of handling conflicts. Dispute systems design recognises conflict resolution is about finding appropriate dispute resolution mechanisms: not every mechanism fits every dispute. Although originally developed to manage disputes within specific organisations, dispute systems design has spread to many types of contexts. In a court context, the concept developed by Frank Sander (1976) of a multi-door courthouse matches the ideas of dispute systems design theory.

In conflicts related to child custody, the level of dispute between the parents vary greatly, as does the reasons for the conflict and the number, nature and difficulty of unresolved issues. Relationships among family members are often complex, and a divorce involving children is seldom, if ever, a clean slate. On the contrary, some form of co-parenting is required at least until the youngest child reaches the age of 18 and often the parents have at least occasional contact long after their children are grown. Consequently, new issues giving rise to new conflicts may occur long after separation. Because the situations of each family is different, families should be offered a range of dispute resolution and other services.

\footnotetext{
${ }^{1}$ In conflict theory, some authors make a distinction between disputes and conflicts. In this text, the terms are used interchangeably.
} 
This text discusses the Norwegian system for resolving child custody and contact disputes in the light of current knowledge on child custody mediation and other forms of child custody alternative dispute resolution (ADR). Particular emphasis is on high conflict families, a diverse group of families with prolonged conflicts, as finding appropriate mechanisms for this group is particularly challenging.

First, this text discusses the development of child custody mediation from facilitative mediation to both diversification of services and dilution of the idea of mediation (Sect. 2). In Sect. 3, the Norwegian child custody mediation and its background are presented. Thereafter, the Norwegian system is subject to criticism both from the perspective of dispute systems design theory and child custody mediation theory. Finally, some proposals to improve the system are offered.

\section{Child Custody Mediation from Facilitative Mediation to Diverse Mediation Models}

\subsection{Child Custody Mediation as Facilitative Mediation}

Child custody mediation draws on the theory of facilitative mediation. The role of the mediator is to facilitate negotiation between the parents by helping them identify and name the disputed issues, their interest and needs. Based on these, the mediator helps create options the parents can select to fulfil their interests. Child custody mediation theory recognised early the particular character of the disputes related to children: the close relationship between the parents, the high level of emotions, the social, psychological, emotional and economic importance of the outcome, and the need for future cooperation. The parents are recognised as the persons who are best equipped to solve disputes in the family. The task of the mediator is to help the parents overcome emotional, social and cognitive barriers to conflict resolution and teach the parents conflict resolution skills (Firestone and Weinstein 2004; Schepard 2004; Kelly 1997).

The best interests of the child is recognised as the epitome of the process. Consequently, mediation needs to focus on the interests of the child, on emotions and social relationships, and on teaching dispute resolution skills. For mediation to be an appropriate method of dispute resolution, both parents must be capable to offer the child adequate care. Additionally, for the outcome to be in the best interests of the child, both parents must be able to perceive the needs and interests of the child and to act accordingly. The parents often need the mediator to help them in recognising the needs and interests of the child (Schepard 2004; AFCC Model Standards of Practice for Family and Divorce Mediation 2000).

Divorce is not a single event. Rather, it is as a long-term process of restructuring a family. Furthermore, new disputes may arise as circumstances change: children's needs change as they grow, the parents' employment changes, new partners and halfor step-siblings become part of the family. To ease adjustment and family 
restructuring, mediation should preferably consist of short hearings over a period of time rather than a one-off ("marathon") session.

From the late 1980s and onwards, in the wake of proliferation of child custody mediation, critical voices were raised at some of its shortcomings. One shortcoming is related to the diverse needs of families, in particular, families with high levels of conflict. Another problem is related to how mediation is implemented as a shortcut to swift resolution and cost-savings rather than recognising the qualities of mediation and the preconditions for achieving successful results.

\subsection{Adapting Mediation to the Needs of Diverse Families}

Domestic violence was the first problematic issue to receive attention in mediation theory. Violence, be it physical, sexual, economical, emotional or psychological, shifts the power balance between the parents and hampers the parents' ability to solve problems. It has adverse effects on the children, regardless of whether the children are the direct target of violence. Therefore, (facilitative) mediation may lead to undesirable outcomes. However, violence is not always easy to spot and not all violence is the same. In some families, it is a single episode triggered by frustration. In other families, one or both parents regularly resort to violence to resolve conflicts. In still others, one parent uses violence to exert power and dominate the entire family. Consequently, in order to determine the appropriate type of dispute resolution process, one must assess whether violence is present in the family and what type of violence is present (Holt et al. 2008; Jaffe et al. 2008).

A persistent high level of conflict is typical for families experiencing domestic violence. Research shows many other factors may also result in high conflict. An estimate of 15-25\% of families are believed to be high conflict in many Western countries (Ottosen 2016; Helland and Borren 2015; Brown 2011; Johnston et al. 2009). High conflict families are not a coherent group: The conflict may arise inter alia from health problems, substance abuse, socio-economic problems, and psychological factors. In some families, the children run a risk of abuse or neglect. They may also be a witness to violence. The risk factors for high conflict are also factors that increase the level of care the child needs, the capability of a parent to provide care for the child, the parent's ability to make decisions, or any combination of theses.

Facilitative mediation, as a short-term intervention, focusing on removing some obstacles of rational decision-making, is often not appropriate or sufficient to solve the disputes in these families. However, litigious court proceedings with an expert evaluation often leads to further escalation (Sauer 2007). Therefore, new forms of mediation have emerged particularly in the English-speaking world to better serve high conflict families. Mediation may be conducted in exclusively in separate meetings (caucuses) where the parents sit in different rooms and the mediator moves between the rooms. The parents may be offered services such as parental education, individual discussions or therapy in addition to mediation. Mediation may 
be combined with other types of dispute resolution processes, such as regular court proceedings, evaluation or arbitration. In helping families with particular challenges, the mediator must have sufficient knowledge and skills to help the family. For example, disputes arising from cultural and religious issues may require a different set of skills than disputes arising from substance abuse, parenting a disabled child, or handling a parent who has developed pathological hatred towards the other parent.

Examples of more intensive forms of mediation is therapeutic family mediation developed by Irving and Benjamin (2002), where mediators use methods and theories from family therapy. Johnston et al. (2009) have developed a method where parents and children are required to participate in short-term therapy on a group or individual level as a parallel process to mediation. Other types of dispute resolution combine mediation with evaluation or arbitration. The most widespread is perhaps parenting coordination, also known as parenting consulting or special master. The parenting coordinator helps the parents to implement the mediated agreement and to solve problems by giving advice, mediating and evaluating. The coordinator may have the right to arbitrate limited issues (Barsky 2011; AFCC Guidelines for Parenting Coordination 2005).

To offer appropriate services, parents participate in a triage-a screening process - to assess the level of conflict, presence of violence and other risk factors at the intake to the mediation programme. The extent and methods used in the screening process vary, but the main goal is to direct the family to an appropriate mediation or other dispute resolution process. In some programmes, other services, such as parent education, therapy and anger management courses are also available.

The result of recognising the diverse situations of dissolving families has been a diversification of mediation and other dispute resolution processes offered. The system must distinguish between different types of services offered to the families. Families should be offered a range of services: advice, therapy, dispute resolution and other services. Each of the services should be labelled appropriately.

\subsection{Mediation Is Diluted to Settlement}

The other development in child custody mediation is less encouraging. Mediation is often introduced both to provide more appropriate dispute resolution than an adversarial trial, which is often detrimental for co-parenting, and to provide cheaper services. However, in many systems the idea of settlement becomes dominating. Mediation is just about settlement, as settlement is seen as something inherently good and in the best interests of the child. Mediation dilutes to a process of settlement: settlement is more important than the quality of the process (and outcome). This view obscures the assets of mediation: the possibility to find interestbased, individualised solutions, teaching the family dispute resolution skills, and -at least to some extent-managing the underlying conflicts. Settlement-oriented mediation may be contrary to the best interests of the child, as the parents may be pressured to accept a solution that is not in the best interests of the child. 
Additionally, they may gain little or no help to solve current and future conflicts. The best interests of the child may become subordinate to settlement. ${ }^{2}$

In this context, the definition of mediation is overly broad. Mediation is the same as any process for reaching settlement. A highly evaluative process where the mediator suggests solutions, or at least indicates a solution, may be, in fact, an adjudicative process, but labelled "mediation". Similarly, a process consisting mainly of therapeutic methods may be labelled "mediation". Mediation may be then almost any type of dispute resolution process or any type of service-or combinations thereof-offered to post-divorce families (c.f. Bernt 2018; Salminen 2018).

The overly broad definition of mediation leads to several problems. It is difficult to direct a family to an appropriate dispute resolution process if everything is labelled mediation. Norway serves as an example. Parents are offered a mixture of services, including some or all of the following: advice, light evaluation, small-scale family therapy, and mediation. Parents may, in practice, not select appropriate services, as all services are offered under the umbrella of mediation. As Bernt (2018) explains, offering mediation as an indistinct group of services also leads to role conflicts. The system is opaque particularly to the families involved-it is difficult to make meaningful selections when the choices are unclear. The family may find itself in a different process than it thought it would enter. In a policy perspective, it may be difficult to develop and assess the services for divorcing and post-divorce families when one does not distinguish between different processes.

\section{Norwegian Child Custody Mediation Systems}

\subsection{Norwegian Welfare State as the Backdrop}

All dispute systems are contingent on the social, cultural and economic context of the surrounding society.

In the Nordic countries, the Nordic welfare state is a paramount societal (and cultural) factor setting the stage of solving issues related to child custody. The Nordic welfare model is highly individualised and based on universal services. Each member of society is expected to provide for himself or herself by working, and pension rights are individual. Spousal maintenance is a rare exception. The government offers a vast range of high quality services free of charge or at a low cost: day care, school, after-school care, higher education, health services, etc. Up until recently, private school and the use of private health care has been limited. Today, private schools are more common, but most of them are state subsidised and

\footnotetext{
${ }^{2}$ Studies indicate that some families in court-connected divorce mediation in Norway feel pressured to settle and some parents settle even if they believe the settlement agreement is contrary to the child's best interests. See Koch (2008), Nordhelle (2011), Breivik and Mevik (2012).
} 
tuition costs are modest. Consequently, in the aftermath of a separation, finance issues are less weighty than in many other Western countries. However, particularly low-income families are often in need of social benefits and may need help to orient themselves to their rights.

Nordic countries encourage parents to solve their issues out-of-court. The preferred way of solving disputes is informal negotiation between the parents or thirdparty facilitated dispute resolution out-of-court. In Norway, only an estimated $10-15 \%$ of parents instigate court proceedings in child custody cases (Koch 2008; Skjørten 2005). ${ }^{3}$

Today, co-habitation is very common in Norway. Approximately one-half of all first-born babies have parents who are not married. The socio-economic differences between co-habiting couples and married couples are small. ${ }^{4}$ Co-habiting couples with children have much of the same rights and obligations as married couplesboth during and after co-habitation.

\subsection{Current Structure of Child Custody Mediation in Norway}

The Norwegian child custody dispute resolution system is three-tiered. All three tiers are regulated by the Children Act. ${ }^{5}$ The first two tiers consist of out-of-court mediation, one of which is mandatory for all separating or divorcing parents with children under the age of 16 . The second step is mandatory pre-action mediation and the third step is court-connected custody mediation.

Children Act section 51 mandates all separating couples with children under the age of 16 to attend mediation at the local Family Counselling Office or a similar service provider. Parents must attend mediation for $1 \mathrm{~h}$. After the first hour, the parents receive a mediation certificate and are entitled to apply for separation and receive benefits for single parents. The mediator may offer the family three additional hours once the first hour has passed. After the four first hours, the mediator may offer an additional $3 \mathrm{~h}$ for a total of $7 \mathrm{~h}$ (Children Act section 54). After $7 \mathrm{~h}$ have passed, mandatory mediation ends, but the Family Counselling Office may continue to work with the family under voluntary services. According to Children Act section 52 , the goal of mediation is to achieve a written agreement on custody, residence and contact and to inform the parents on the financial consequences of the agreement. The Family Counselling Office is mandated to provide parents with information,

\footnotetext{
${ }^{3}$ The percentage is similar in Finland, see Valkama and Lasola (2009).

${ }^{4} \mathrm{Co}$-habiting parents are, on average, slightly younger than married parents, have a shorter history as a couple and have younger children, but the differences are rather small in total, see Ådnanes et al. (2011b), pp. 17-19. The level of conflict is approximately the same in both groups.

${ }^{5}$ Lov om barn og foreldre 8 April 1981 no 7. An unofficial English translation is available at https:// www.regjeringen.no/en/dokumenter/the-children-act/id448389/.
} 
advice and dispute resolution services. In most parts of Norway, children seldom participate in mediation. ${ }^{6}$

The second tier is pre-action mediation where a parent intending to instigate child custody proceedings at court must attend mediation for at least $1 \mathrm{~h}$ and up to $7 \mathrm{~h}$. At the end of the hour, the parents obtain a mediation certificate that is valid for 6 months. During those 6 months, the parents may instigate court proceedings. The license from the initial "mediation" during separation (first-tier mediation) is valid for 6 months: within that period, the parents are not required to participate in additional mediation before instigating litigation. Thus, pre-action mediation takes place several months, or even years, after the initial separation. Mandatory pre-action mediation is subject to the same regulation as mandatory mediation during separation. Yet the target group is different, as only parents who have not found agreement in the initial mediation and parents who face new or recurrent conflicts are included. Although many families face conflicts long after separation, most of them are able to solve the conflicts on their own. Thus, in the pre-action mediation group the level of conflict is, on average, higher than in families participating in mandatory post-separation mediation.

The third tier is court-connected alternative dispute resolution processes, in practice, almost exclusively court-connected mediation. Mediation is the preferred method of dispute resolution in court, and it is used unless there is reason to believe the child could risk abuse or neglect (Children Act section 61). In addition to courtconnected custody mediation, the court may order evaluation, out-of-court mediation and other types of help. However, these are seldom used. In practice, the court appoints an expert to (co-)mediate the case with the judge hearing the case. The expert mediates, provides advice to the parents and the court. The expert-mediator may also make an expert evaluation.

The first two tiers of dispute resolution have a long history. The purpose of mediation was originally to help parents to mend their relationship to avoid divorce. Today, the purpose is to help parents find an agreement that is in the best interests of the child. The minimum number of hours of mandatory mediation was reduced from three to one in 2007. Since mediation should be voluntary, the reduction of mandatory hours could be characterised as a positive development. However, because "mediation" refers to a broader set of services, particularly families with prolonged conflicts could benefit from a longer session with an opportunity to discuss the conflict, its implications for the children and to teach co-parenting skills.

Court-connected custody mediation was introduced in 2004 to offer a form of dispute resolution that would not escalate conflicts in the manner litigation and other adjudicative processes does. Although the legislator recognised that mediation does not fit situations where the child risk neglect or abuse, the model does not take into account the varying needs of families, and, in particular, high conflict families. The

\footnotetext{
${ }^{6}$ Ådnanes et al. (2011b) found children participated in mediation in only $4 \%$ of the cases. Some Family Counselling Offices have adopted a mediation model where the children, as a rule, are included in mediation. See Thørnblad and Strandbu (2018).
} 
model is based on a vague concept of mediation as a conflict reducing dispute resolution mechanism. The legislator recognised many of the promises of mediation, but disregarded research and experience from other countries indicating shortcomings and pitfalls of short-term facilitative mediation, including the limited help it offers to many high-conflict families and some of the perils of mixing different types of services under the label of "mediation" (Nylund 2008, 2011).

\section{Critical Perspectives on Norwegian Child Custody Mediation}

In this part, three key points of criticism will be raised. Firstly, the current system has an unclear target group, is an incongruent mixture of elements and a connection between the forms of mediation is lacking. Furthermore, Norwegian mediation can be criticised for allowing the mediator to mix roles, for not securing the children's right to participation in decision-making and for having mandatory mediation. However, the three latter issues will not be discussed in this text.

\subsection{Unclear Target Group}

Norwegian child custody mediation has an unclear target group. Two decades ago, Ekeland and Myklebust (1997) noted that mediation in Family Counselling Offices did not recognise the various need of families. Mandatory mediation at separation is targeted at all separating families. Thus, the level of conflict and the number of and severity of risk factors for the well-being of the child and for high conflict vary. Many parents would find, and actually have found, a solution on their own. Low conflict families do not need dispute resolution services. However, they may wish to have information on shared parenting, supporting the children, factors they should take into account when selecting care arrangements and social benefits.

Families with moderate conflicts may benefit from mediation. However, settlement, as such, may not be the key issue in the family. Rather, the parents may need help to improve communication, discuss specific issues and recognise the best interests of their child(ren). Discussing some of the issues or providing facilitative mediation requires more than $1 \mathrm{~h}$ and may require, in many cases, more than $7 \mathrm{~h}$.

Finally, high conflict families often need more intensive and more specialised services than low to moderate conflict families. In some cases, mediation may not be an appropriate dispute resolution method and may even put the child at risk of abuse or neglect. In other high conflict families, dispute resolution services should be tailored to give the families proper help. In absence of a screening mechanism and in light of the limited first session, one may ask if the particular needs of each family are identified and if, and how, the services can be tailored to each family 
(Gulbrandsen 2013; Gulbrandsen and Tjersland 2013; Ådnanes et al. 2011a). More than one-half of the high conflict families leave mediation after 1 or $2 \mathrm{~h}$ without agreement and without reduction in the level of conflict (Tjersland et al. 2015). Currently, some Family Counselling Offices are piloting a model for high conflict families where a set of individual, family and group sessions are combined. In the model, two employees "co-mediate" to offer the best help to reduce the level of conflict. The initial results are encouraging, with more families engaging in mediation beyond the first mandatory hour.

In Norway, neither mandatory pre-action mediation nor court-connected custody mediation has been designed with high conflict families in mind. Considering that only $10-12 \%$ of families instigate child custody proceedings in court, there is reason to believe a notable part of the families have a persistent high level of conflict. Yet the bill that introduced court-connected custody mediation hardly touches upon the topic of high conflict families. It seems to presuppose families belong to two categories: one where the child risks abuse or serious neglect and one where the parents are stuck in a conflict but are able to resolve it if the mediator focuses on constructive communication and the positive experiences of co-parenting. In fact, many families fall between these categories: the child does not risk serious neglect, but focusing on improving communication and positive experiences will not suffice to reduce the level of conflict (Tjersland et al. 2015; Nylund 2012; Nylund 2011; Ådnanes et al. 2011a; Nylund 2008). There is also a widespread notion that a conflict is never the fault of one party. Rather, the reason for persistent conflict lies with both parties. However, often the behaviour of one parent is an important source of conflict (Gulbrandsen 2013; Dutton et al. 2011; Demby 2009). Nonetheless, a skilled mediator cannot regard one parent as the "good one" and the other as the "bad one". Nor can a mediator necessarily assume that both parents have equal fault and equal parenting skills. Given the complexity of familial relationships, the mediator needs sufficient tools to deal with a range of reasons for persistently high levels of conflict.

Norway is the only Nordic country with mandatory mediation for all separating couples and the only Nordic country with mandatory pre-action mediation. Denmark has a system with a mandatory pre-trial counselling or mediation session. The service is similar to the Norwegian model of services, but it distinguishes between family counselling and mediation. Both services are in addition separate from adjudicative processes (www.statsforvaltningen.dk). In Finland and Sweden, mediation is offered on a voluntary basis outside courts. Yet the percentage of divorcing families instigating child custody litigation is roughly the same.

Although the research community has recognised that the current system does not serve the needs of high conflict families, the system has been subject to limited discussion. Currently, no triage mechanisms are in place to assess the conflict level in the family and the sources of conflict, nor to determine appropriate services. Mediators are not offered systematic training on issues related to high conflict families. Therefore, families are offered inappropriate or inadequate services to help them manage their conflict and teach them effective post-divorce parenting skills. 


\subsection{Overly Broad Definition of Mediation}

Mediation is defined very broadly. At the Family Counselling Office "mediation" consists of information, advice, brief therapy and dispute resolution. Mediation may be facilitative, evaluative, therapeutic, narrative, transformative or simply trying to induce the parents to settle. The consequence of an unclear concept of mediation and bundling of services is that families often leave mediation after the first hour (Kjøs et al. 2015; Tjersland et al. 2015; Gulbrandsen 2013; Ådnanes et al. 2011a, b; Gulbrandsen and Tjersland 2010; Haugen and Rantalaiho 2010). Thus, the positive potential that mediation and other services could offer remains untapped.

According to the mediators, mediation is often ritualised, as the regulations do not give them the power or tools to deal with the underlying conflicts. Most parents leave after the mandatory first hour without getting much help to manage the conflict. Furthermore, both parents and mediators find that many of the settlement arrangements arrived at during mediation are sub-optimal. Parents agree to a mediated settlement because they fear court proceedings could lead to a worse option, not because they find the mediated agreement good.

When mediation is a mélange of services, the family may not pick the most relevant services. Families with low or moderate levels of conflict may reject the services because they do not need help to resolve a conflict, as they have already agreed on most issues. This may be true, however, they may like to discuss the needs of the children or challenges related to co-parenting. Families with underlying risk factors, regardless of the level of conflict, could find it helpful to discuss the underlying problem. However, they may not be aware of the services available to them or the mediator may lack (sufficient) training on the issue. In some families, key issues may remain unnoticed due to a lack of proper screening and awareness of the mediator.

As the source of the persistent conflicts is not recognised or the mediator lacks the knowledge and skills to provide a successful intervention, many families run a risk of not receiving the help they need. If the families perceive that the Family Counselling Office has limited help to offer, they may not be induced to participate in mediation apart from the mandatory first hour.

The limited timeframe for mediation may also hamper mediation. Successful interventions may be time-consuming-both in terms of the number of mediation sessions and the time-span of mediation. Hence, mediation is often not an avenue to swift resolution. The more limited the timeframe and the more the focus lies on settlement, the more parents may feel pressured to adopt a dissatisfactory settlement. This is probably particularly true in a country such as Norway where going to court is the exception. In Norway, it is generally understood that a "successful" divorce is a "happy" divorce where the parents agree on all issues.

In third-tier court-connected custody mediation, the understanding of mediation is broad. The tasks and roles of the mediator are manifold and may lead to conflicting roles and use of contradictory strategies. The methods of "mediation" are not standardised, nor is there committed work towards developing guidelines for best 
practices. While uniformity should certainly not be a goal in itself, continuous and persistent work towards developing practices would be beneficial to improve the quality of services and assure appropriate interventions.

Section 61 of the Children Act regulates court proceedings in child custody cases. In addition to court-connected custody mediation (expert-led or assisted) and a regular trial, the judge can request the parties to mediate at the Family Counselling Office or another out-of-court mediation programme. Although the provision is silent on the use of other types of dispute resolution processes, the legislator has clearly understood mediation in a broad manner. The role of the court-appointed expert-mediator is to give advice to the parents. Moreover, the expert-mediator may use evaluative techniques. Thus, mediation could be a highly, or almost purely, evaluative process. Evaluation could be appropriate in some situations, but, in other situations, it could be counterproductive. Therefore, using evaluation requires knowledge and skills on the when and how evaluation is appropriate (Bernt 2018).

Court-appointed experts and staff at Family Counselling Offices are licensed psychologists, social workers or psychiatrists, often with a specialisation in families and some additional training. However, no mediation training is required, nor are there any guidelines as to the content of such training. Training on issues related to specific issues is haphazard. The lack of comprehensive mediation training reduces the awareness of the concept of mediation, its uses and abuses, techniques used in mediation and the relationship between mediation and other forms of dispute resolution.

A particular problem related to offering mediation as a mélange of different services relates to consent. If almost any service or method for resolving disputes fits within the definition of mediation, then the families will not know which type of process they consent to. The right to informed decision-making and selfdetermination is reduced. Monitoring quality becomes difficult or almost impossible. In court-connected custody mediation, leaving the process may be difficult, particularly when the option is litigation where the expert mediator shifts to the role of expert evaluator, and the judge-mediator becomes the judge (Bernt 2018).

\subsection{Relationship Between the Three Tiers of Mediation}

Ideally, a dispute system should be designed to prevent conflicts from arising and escalating. Disputes should be resolved at the lowest possible level using the least intrusive mechanisms. Each level in the system should build on the earlier levels and bring loops back to the lower levels of the system.

The Norwegian child custody dispute system is incoherent. The same rules regulate the first two tiers, mandatory post-separation mediation and mandatory pre-action mediation, but fail to recognise the difference between the needs of the target group. In mandatory pre-action mediation, the family has already faced separation and lived with separation for at least 6 months. The conflict level is on average higher, and risk factors are more prevalent. Still, the rules and regulation are identical. 
Court-connected custody mediation is, in practice, fully separated from mediation in Family Counselling Offices. Family Counselling Offices do not provide information to the court on mediation or risk factors present in the families. Thus, mediation in courts starts as if there had not been earlier attempts to mediate the case. Even though a family has only participated in the first mandatory hour of pre-action mediation, only a few courts regularly loop cases back to the Family Counselling Office. Although exchange of information may compromise the confidentiality of mediation, and sending a case back for mediation may pressure parents to settle, outof-court mediation and court-connected custody mediation should be coordinated. The system should be more coherent with each level building on previous levels and better coordination between the levels.

In a comparative context, mandatory mediation for separating families and mandatory pre-action mediation does not seem to have reduced the percentage of families resorting to court proceedings. The system's design does not seem better than in countries with voluntary mediation.

\subsection{Particular Problems Related to Court-Connected Custody Mediation}

Court-connected custody mediation is the rule in cases on child custody, residence and contact. Mediation is seen quite uncritically as a superior method of dispute resolution, suitable to most cases. The only exception is cases where the child risks abuse or neglect.

The regulation is based loosely on theories of general child custody mediation and blatantly disregards the discussions on high conflict families. Considering only approximately $10 \%$ of all separating parents instigate court proceedings, many if not most of these families could probably be characterised as "high conflict". Consequently, the dispute resolution system should be set up accordingly.

Currently, no triage is in place. Judges trust that legal counsel will mention any relevant information indicating child abuse or neglect to enable the judge to direct the case to traditional court proceedings rather than court-connected custody mediation. There is no uniform standard of what constitutes abuse or neglect disqualifying the case from mediation. If physical violence is present in the family, does only violence against the child disqualify mediation? Does severe violence against a parent also disqualify a case and, if so, on what grounds? Although the families have attended mediation at the Family Counselling Office, there is usually no exchange of information between courts on the level of conflict or sources of conflict. Neither does the court use triage.

The content of mediation and the role of the mediators are discussed in more detail by Camilla Bernt (2018). Here, it is sufficient to make a few remarks on mediation vis-à-vis providing diversified services. First, the court invites an expert to assist the court in mediating the case by providing information and advising the 
parents, and, if necessary, to decide the case. In spite of the widespread use of experts, the training does not have sufficient focus on mediation and issues in high conflict families. Experts without the specific training are frequently used. The content of the training is geared particularly towards the traditional role of a court appointed expert rather than that of a mediator, parenting coach and counsellor (Agenda Kaupang 2017).

Awareness of different causes of high conflict levels is relatively low particularly among judges, as is the knowledge of their consequences on parenting and the children. ${ }^{7}$ When combined with an understanding of mediation as an inherently good form of dispute resolution and settlements as inherently good outcomes, the result may be less than optimal. Some parents report that when they voice a concern for substance abuse problems, or even (sexual) abuse of the child, the allegation might turn against them. The parent voicing the concern is accused of using a tactic of escalation or an attempt at disrupting the process towards settlement. The focus on settlement results in some parents feeling pressured into a settlement they do not agree with (Stang 2013; Koch 2008).

\section{Improving Child Custody Mediation}

The Norwegian child custody dispute system should be improved in several ways to address the issues of a lack of coherence and differentiation between families. First, differences in the family situations should be recognised, as the level and sources of conflict vary significantly. Consequently, families should be offered different types of help. Second, conflicts should be solved early to avoid escalation and the family taught dispute resolution skills to reduce future conflicts. Third, the system should offer transparent, coherent services where the different types of services are distinguished and where each step builds on the former steps.

\subsection{Recognising the Needs of High Conflict Families}

An essential step to improving the system is to recognise the diverse situations and needs of families. Since solving - or at least managing - disputes in high conflict families is a challenge, identifying families with a high conflict level is essential. In order to do so, services should be based on an initial assessment, triage of the situation, and needs and wishes of each family. Assessment of the conflict level

\footnotetext{
${ }^{7}$ The Norwegian Institute of Public Health issued a report on high conflict families (Helland and Borren 2015). The report provides research on how a high level of conflict is manifested, the reasons for high conflict and risk factors behind it. However, the report does not discuss how the high conflict level can be managed or reduced or how mediators should identify or deal with it.
} 
and sources of conflict does not presuppose an extensive triage. Rather, simple tools and increased awareness, vigilance and knowledge may suffice. Based on the assessment, families should be directed to appropriate services. The Family Counselling Offices have the infrastructure and much of the tools necessary to do so. Ideally, an assessment tool would be developed to ensure consistent quality and limit the resources spent on assessment.

Currently mediators report having too little knowledge of particular problems and sources of conflict such as violence, child abuse, substance abuse and questions related to ethnicity and religion (Agenda Kaupang 2017; Ådnanes et al. 2011b). By increasing the competency of mediators, family counsellors, psychologists and other professionals working with child custody and contact issues, the needs of families facing particular challenges and high conflict families will be recognised and addressed earlier and in appropriate ways.

\subsection{Preventing Conflicts and Conflict Escalation}

A key concept in dispute systems design is to create an organisation that reduces the number of disputes and prevents disputes from escalating. Teaching conflict management skills and implementing mechanisms for early intervention is essential.

To improve the Norwegian child custody mediation system, services should be unbundled and distinguished from each other. I do not advocate total separation of processes, where a mediator is banned from using any type of therapeutic or therapyinspired intervention, or where a mediator should never give parents any general information. Rather, different services should be offered, and each family should be able to assemble a set of services.

Families with low- to medium-levels of conflict may find information on postdivorce parenting, conflict management and supporting the children emotionally helpful. Online resources on parenting skills, discussion groups or meetings where a member of the staff facilitates a discussion on adjustment to a new family situation could be some of the services fit for families. Helping the parents recognise the views and perspectives of the children would probably be beneficial for many families. Labelling the help "mediation", as is currently done, makes the system opaque, as the families do not know what services are available. Further, many families may not find the services attractive, since the level of conflict is low, and they have settled all issues.

Appropriate labelling is not sufficient to unbundle services. Families, including children, should be informed of the services offered. Role conflicts and confusion of services should be avoided by letting different people perform different roles. This should be the case particularly when a family receives services that are more extensive. Thus, one counsellor could offer information and a discussion on postdivorce parenting and the impact of conflict on the well-being of children, a second could offer therapeutic services and a third could function as a mediator. Different services requires different skills from the person offering the service. Although a 
family therapist may also be a good facilitative or therapeutic mediator, not all family therapists are qualified mediators; nor does a mediator have to be a therapist.

If families believe the services offered are appropriate for their needs, they are more likely to be motivated to use them and return for more help and assistance when needed. Focus should not be on settlement, but on offering families help to adjust to post-divorce life and specialist services for post-divorce families. Conflict may arise long after the divorce, as new partners and children become part of the family, as the children grow and as the life-situations, such as employment and health, of the family members change. Parents who have learned co-parenting skills and dispute resolution skills, or who are at least aware of the services offered, are probably more likely to return for early dispute resolution services, if necessary.

\subsection{Transparent, Coherent and Unbundled Services}

Today, the system lacks coherence. A family is directed through a set of sessions labelled "mediation". In the Family Services Office, the session far too often ends after the first hour, and in courts, the sessions are longer but their content is mixed and often evaluation-driven. The entire system is also settlement-oriented rather than focusing on finding interest-based, child-friendly solutions.

A mandatory intake discussion, where the family discusses its current situation and, when appropriate, receives advice could be combined with an intake assessment, triage, where the family counsellor informs and advices about services and assesses the needs of the family.

After the intake assessment, families where the children risk child abuse or neglect would be directed directly to the court. Other families receive appropriate services based on the assessment. Although mediation and counselling should not be mandatory, parents should receive information about the content and benefits of the services. Keeping families within the Family Counselling Office system would provide them with an opportunity to solve their conflicts early.

Second-tier mediation, mandatory pre-action mediation, should to a greater degree be connected with court proceedings. Requiring the families to take part in an intake discussion and assessment at the Family Counselling Office would serve two aims. First, to encourage the family to use dispute resolution process on a lower level to reduce the level of conflict, to keep the decision-making power within the family, to reduce costs and obtain better outcomes. Second, the Family Counselling Office would assist the court in assessing the level and sources of conflict.

Courts should still offer court-connected custody mediation, but building on the work done at the Family Counselling Office. Courts should also loop back families to the Family Counselling Office when appropriate.

By making the system more coherent, overlapping services could be avoided and families could be encouraged to use less invasive, less conflict-driving dispute resolution mechanisms and other services that enhance the ability of the family to solve conflicts and provide children with good parenting. 


\section{References}

Ådnanes M, Haugen GMD, Jensberg H, Husum TL, Rantalaiho M (2011a) Hva karakteriserer vanskelige saker i foreldremekling, og er meklingsordningen godt nok tilpasset? Fokus på Familien 39:86-115

Ådnanes M, Haugen GMD, Jensberg H, Rantalaiho M, Husum TL (2011b) Rapport. Evaluering av mekling etter ekteskapslov og barnelov. SINTEF Teknologi og samfunn. NTNU Trondheim

AFCC Model Standards of Practice for Family and Divorce Mediation (2000) Association of Family and Conciliation Courts

AFCC Guidelines for Parenting Coordination (2005) Association of Family and Conciliation Courts

Agenda Kaupang (2017) Evaluering av utdanningsprogramme for barnefaglige sakkyndige. Barneog likestillingsdepartementet, Oslo

Barsky AE (2011) Parenting coordination: the risks of a hybrid conflict resolution process. Negot J 27:7-27

Bernt C (2018) Custody mediation in Norwegian courts: a conglomeration of roles and processes. In: Nylund A, Ervasti K, Adrian L (eds) Nordic mediation research. Springer, Cham, pp 105-132

Bingham LB (2008) Designing justice: legal institutions and other systems for managing conflict. Ohio State J Dispute Resolut 24:1-51

Breivik FL, Mevik K (2012) Barnefordeling i domstolen. Når barnets beste blir barnets verste. Universitetsforlaget, Oslo

Brown H (2011) Mediating high conflict couples. In: Deleuran P, Jarner S (eds) Conflict management in the family field and in other close relationships. DJØF Publishing, Copenhagen

Demby S (2009) Interparent hatred and its impact on parenting: assessment in forensic custody evaluations. Psychoanal Inq 29:477-490

Dutton DG, Denny-Keys MK, Sells JR (2011) Parental personality disorder and its effects on children: a review of current literature. J Child Custody 8:268-283

Ekeland T-J, Myklebust V (1997) Foreldremekling: brukarperspektiv. Møreforskning, Volda

Firestone G, Weinstein J (2004) In the best interests of children family. Court Rev 42:203-215

Helland MS, Borren I (2015) Foreldrekonflit; identifisering av konfliktnivåer, sentrale kjennetegn og risikofaktorer hos høykonfliktpar. Folkehelseinstituttet rapport 2015:3

Gulbrandsen W (2013) Foreldrekonflikter etter samlivsbrudd: En analyse av samspill og kilder til det fast-låsende. Tidsskrift for norsk psykologforening 50:538-551

Gulbrandsen W, Tjersland OA (2010) Mekling ved samlivsbrudd: en oversikt over effektstudier. Tidsskrift for norsk psykologforening 47:705-714

Gulbrandsen W, Tjersland OA (2013) Hvordan virker obligatorisk foreldremekling ved store konflikter? Tidsskrift for velferdsforskning 16

Haugen GMD, Rantalaiho M (2010) Barns rettigheter i mekling ved separasjon og samlivsbrudd. In: Kjørholt AT (ed) Barn som samfunnsborgere. til barnets beste? Universitetsforlaget, Oslo, pp 111-131

Holt S, Buckley H, Whelan S (2008) The impact of exposure to domestic violence on children and young people: a review of the literature. Child Abuse Negl 32:797-810

Irving HH, Benjamin M (2002) Therapeutic family mediation. Sage Publications, Thousand Oaks

Jaffe PG, Johnston JR, Crooks CV, Bala N (2008) Custody disputes involving allegations of domestic violence: toward a differentiated approach to parenting plans. Fam Court Rev 46:500-522

Johnston JR, Roseby V, Kuehnle K (2009) In the name of the child. A developmental approach to understanding and helping children, 2nd edn. Springer, New York

Kelly JB (1997) The best interests of the child. Fam Court Rev 35:377-387

Kjøs P, Madsen OJ, Tjersland OA (2015) 'Barnets beste' i mekling ved samlivsbrudd. Tidsskrift for Norsk Psykologforening 52:570-579 
Koch K (2008) Evaluering av saksbehandlingsreglene for domstolene i barneloven - saker om foreldreansvar, fast bosted og samvær. Barne- og likestillingsdepartementet (Department of Children and Equal Opportunity), Oslo

Menkel-Meadow CJ, Love LP, Schneider AK, Sternlight JR (2010) Dispute resolution: beyond the adversarial model, 2nd edn. Wolter Kluwer, New York

Nordhelle G (2011) Praktiseringen av sakkyndighetsarbeid i barnefordelingssaker. Tidskrift for familierett, arverett og barnevernrettslige spørsmål:176-197

Nylund A (2008) Til domstol - med barnet i fokus. Tidskrift for familierett, arverett og barnevernrettslige spørsmål 6:229-243

Nylund A (2011) Mekling i barnefordelingssaker på godt og ondt. Tidskrift for familierett, arverett og barnevernrettslige spørsmål 9:302-322

Nylund A (2012) Barnefordelingssaker og 'familier med høyt konfliktnivå'. Tidskrift for familierett, arverett og barnevernrettslige spørsmål 10:215-235

Ottosen MH (2016) Analyse om udviklingen i familieretlige konflikter. SFI Det Nationale Forkningcenter for velfærd, Copenhagen

Rogers NH, Bordone RC, Sander FEA, McEwen CA (2013) Designing systems and processes for managing disputes. Wolters Kluwer, New York

Salminen K (2018) Is mediation in the best interests of the child from the child law perspective? In: Nylund A, Ervasti K, Adrian L (eds) Nordic mediation research. Springer, Cham, pp 209-222

Sander FE (1976) The multi-door courthouse. Barrister 3:18

Sauer JJ (2007) Mediating child custody disputes for high conflict couples: structuring mediation to accommodate the needs \& desires of litigious parents. Pepperdine Dispute Resolut Law J 7:501

Schepard AI (2004) Children, courts and custody. interdisciplinary models for divorcing families. Cambridge University Press, Cambridge

Skjørten K (2005) Samlivsbrudd og barnefordeling. Gyldendal, Oslo

Smith S, Martinez J (2009) An analytic framework for dispute systems design. Harv Negot Law Rev 14:123-170

Stang EG (2013) Når vi ikke får gehør i rettsapparatet har vi tapt på vegne av barnet. In: Søvig KH, Schütz SE, Rasmussen $\varnothing$ (eds) Undring og erkjennelse. Festskrift til Jan Fridtjhof Bernt 70 år. Fagbokforlaget, Bergen, pp 665-678

Thørnblad R, Strandbu A (2018) The involvement of children in the process of mandatory family mediation. In: Nylund A, Ervasti K, Adrian L (eds) Nordic mediation research. Springer, Cham, pp 183-208

Tjersland O, Gulbrandsen W, Haavind H (2015) Mandatory mediation outside the court: a process and effect study. Confl Resolut Q 33:19-34

Valkama E, Lasola M (2009) Lasten huoltoriidat tuimioistuimissa. In: Litmala M (ed) Oikeusolot 2009. Katsaus oikeudellisten instituutioiden toimintaan ja saatavuuteen. Oikeuspoliittisen tutkimuslaitoksen julkaisuja, vol 244. Oikeuspoliittinen tutkimuslaitos, Helsinki, pp 233-256

Open Access This chapter is licensed under the terms of the Creative Commons Attribution 4.0 International License (http://creativecommons.org/licenses/by/4.0/), which permits use, sharing, adaptation, distribution and reproduction in any medium or format, as long as you give appropriate credit to the original author(s) and the source, provide a link to the Creative Commons license and indicate if changes were made.

The images or other third party material in this chapter are included in the chapter's Creative Commons license, unless indicated otherwise in a credit line to the material. If material is not included in the chapter's Creative Commons license and your intended use is not permitted by statutory regulation or exceeds the permitted use, you will need to obtain permission directly from the copyright holder.

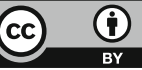

